University of Nebraska - Lincoln

DigitalCommons@University of Nebraska - Lincoln

Management Department Faculty Publications

Management Department

8-2007

\title{
The role of leadership in emergent, self-organization
}

Donde Ashmos Plowman

University of Nebraska-Lincoln, dplowman2@unl.edu

Stephanie Solansky

University of Houston-Victoria, solanskys@uhv.edu

Tammy E. Beck

University of Houston-Clear Lake, tbeck8@unl.edu

LaKami Baker

Mississippi State University

Mukta Kulkarni

Indian Institute of Management, Bangalore, India

See next page for additional authors

Follow this and additional works at: https://digitalcommons.unl.edu/managementfacpub

Part of the Management Sciences and Quantitative Methods Commons

Plowman, Donde Ashmos; Solansky, Stephanie; Beck, Tammy E.; Baker, LaKami; Kulkarni, Mukta; and Travis, Deandra Villarreal, "The role of leadership in emergent, self-organization" (2007). Management Department Faculty Publications. 64.

https://digitalcommons.unl.edu/managementfacpub/64

This Article is brought to you for free and open access by the Management Department at DigitalCommons@University of Nebraska - Lincoln. It has been accepted for inclusion in Management Department Faculty Publications by an authorized administrator of DigitalCommons@University of Nebraska - Lincoln. 


\section{Authors}

Donde Ashmos Plowman, Stephanie Solansky, Tammy E. Beck, LaKami Baker, Mukta Kulkarni, and Deandra Villarreal Travis 
Published in The Leadership Quarterly 18:4 (August 2007), pp. 341-356; doi: 10.1016/j.leaqua.2007.04.004

Copyright (c) 2007 Elsevier Inc. Used by permission.

Published online June 13, 2007.

\title{
The role of leadership in emergent, self-organization
}

\author{
Donde Ashmos Plowman, ${ }^{1}$ Stephanie Solansky, ${ }^{2}$ Tammy E. Beck, ${ }^{3}$ \\ LaKami Baker, ${ }^{4}$ Mukta Kulkarni, ${ }^{5}$ and Deandra Villarreal Travis ${ }^{1}$
}

1. The University of Texas at San Antonio,

Department of Management, San Antonio, TX 78249, USA

2. University of Houston-Victoria, TX, USA

3. University of Houston-Clear Lake, TX, USA

4. Mississippi State University, MS, USA

5. Indian Institute of Management, Bangalore, India

Corresponding author - D. A. Plowman

\begin{abstract}
As complex systems, organizations exist far from equilibrium where the ongoing interaction of system components leads to emergent and self-organizing behavior. What, then, is the role of leadership in systems where change often emerges in unexpected ways? In this paper, we build on the work of Marion and Uhl-Bien who suggest that in complex systems leaders enable rather than control the future. While traditional views of leadership focus on the leader's responsibility for determining and directing the future through heavy reliance on control mechanisms, we offer empirical support for a different view of leadership based on a complexity perspective of organizations. Our findings show that as enablers, leaders disrupt existing patterns of behavior, encourage novelty, and make sense of emerging events for others. The results of our qualitative study include a set of research propositions as well as a discussion of the implications for managers and researchers.
\end{abstract}

Keywords: leadership, complexity theory, emergence, self-organization

I wanted a perfect ending. Now I've learned, the hard way, that some poems don't rhyme, and some stories don't have a clear beginning, middle, and end. Life is about not knowing, having to change, taking the moment and making the best of it, without knowing what's going to happen next. Delicious Ambiguity.

- Gilda Radner

Although many would agree that life is ambiguous, the study of leadership in organizations has often been approached as if leaders should know what is going to happen next, as if effective leaders can eliminate the ambiguity that characterizes much of organizational life. Traditional views of leadership grow out of the long-held view of organizations as equilibrium-seeking systems whose futures are knowable and arrived at by leaders who plan interventions and control behaviors (Stacey, 1992; Wheatley, 1999). However, in recent years complexity theory has 
made its way into organizational science, challenging this linear, mechanistic view of organizations with analogies from the physical sciences of systems whose future states are unpredictable and full of surprise (Anderson, 1999; McKelvey, 1999; Richardson and Cilliers, 2001). A central principal of complexity theory is emergent self-organization, whereby systems achieve order because multiple local agents interact and those interactions produce unintended outcomes without the intervention of a central controller (Chiles, Meyer, \& Hench, 2004). Thus, organizations take on properties and structures that are unexpected (McKelvey \& Lichtenstein, in press) because people and groups interact and the results of those interactions produce perpetual novelty. What, then, is the role of leadership in complex organizations? If leaders cannot predict and control the organization's future, what do leaders do?

In this paper, we present a theoretical framework for re-conceptualizing leadership in complex adaptive organizations based on the work of McKelvey (1999), Maguire \& McKelvey (1999), Marion \& Uhl-Bien (2001), McKelvey \& Lichtenstein (in press), and others. We base our framework on: (1) characteristics of complex adaptive systems, whose central feature is emergence, and (2) observations from a qualitative case study of a dying organization that underwent a major unintended radical change, which ultimately proved successful in reversing the decline (Plowman, Baker, Beck, Kulkarni, Solansky, \& Travis, 2007). The case study on emergent radical change provided us the unique opportunity to re-visit our data and observe closely what it was that the leaders, who did not initiate the radical change, actually did as the organization's future was emerging. The research question driving this study was how do leaders enable emergent, self-organization?

We begin with an overview of complex adaptive systems, with particular focus on emergent, self-organization. A review of existing leadership literature, however, confirms that most approaches to the study of leadership emphasize the role of leaders in directing organizations towards seemingly knowable and controllable futures. In this study we rely on a qualitative theory development approach (Miles and Huberman, 1994; Yin, 2003) and find support for Marion \& Uhl-Bien's (2001) notion that complex leaders enable rather than control desirable futures. Further, we identify three mechanisms that the leaders used and seven specific actions they took as enablers of productive futures. Our findings allow us to offer theoretical propositions for use in further research on leadership in complex adaptive systems.

\section{Literature review}

The topic of leadership remains popular in spite of years of criticism from organizational scholars. For example, in their highly cited paper, Kerr \& Jermier (1978) minimized the significance of leadership by identifying "substitutes" for leadership. Yet, twenty-seven years later, publications like Harvard Business Review and others continue to devote considerable space to articles on leadership, such as a recent paper by Quinn (2005) who identified the qualities that enable one to enter the "fundamental state of leadership." More than twenty years ago Meindl, Ehrlich \& Dukerich (1985) argued that people romanticize leadership and often attribute to leadership otherwise ambiguous organizational events. However, 16 years later, authors such as Collins (2001) argue that organizational greatness is due to one fundamental ingredient: leadership; and in book after book, Kotter $(1985,1990,1996)$ argues it is leaders who make organizational transformation happen by directing the change. While organizational scholars continue to debate how important leadership is, the emerging view of organizations as complex adaptive systems challenges the fundamental premise of what leadership is. Before comparing the assumptions of traditional theories of leadership with those of a complexity theory view of leadership, we offer a brief summary of complex adaptive systems and its central organizing principal: emergent, self-organization.

\subsection{Complex adaptive systems: An overview}

Complexity theory originally developed in the physical sciences where scientists were attempting to understand the complexity of nature, and increasingly found linear models to be ineffective in capturing the complex and emergent nature of phenomenon (Ashby, 1962; Holland, 1995; Kauffman, 1995; Prigogine, 1997). Observing that emergence and perpetual novelty exist throughout nature gave rise to the identification of common characteristics of complex adaptive systems because "in our world we discover fluctuations, bifurcations, and instabilities at all levels" (Prigogine, 1997, p. 55). Some of the characteristics of complex adaptive systems include: (1) they are made up of many agents who act and interact with each other in unpredictable ways, (2) they are sensitive to changes in initial conditions, (3) they adjust their behavior in the aggregate to their environment in un- 
predictable ways, (4) they oscillate between stability and instability, and (5) they produce emergent actions when approaching disequilibrium. Additionally, complex systems are dynamic and non-linear, and rarely explained by simple cause-effect relationships.

Organizational theorists have begun to conceptualize organizations as complex adaptive systems (Anderson, 1999; McKelvey, 2001; Stacey, 1992; Wheatley, 1999) and increasingly reject the more traditional, mechanistic view of organizations because the simple models of classic science it is based on are unworkable (Marion \& Uhl-Bien, 2001). Rather, organizations exist in conditions of instability, and as organizations move further away from equilibrium towards instability, they are capable of highly complex behavior.

\subsubsection{Emergent self-organization}

While complex systems have many characteristics, Chiles, Meyer and Hench describe the concept of emergent self-organization as complexity theory's "anchor point phenomenon" (2004, p. 502). System-level order emerges because of interactions among entities with individual schemas at a lower level in the system (Anderson, 1999), that is, nested systems (Ashmos \& Huber, 1987). In self-organizing systems, order comes from the actions of interdependent agents who exchange information, take actions, and continuously adapt to feedback about others' actions rather than from the imposition of an overall plan by a central authority (Chiles et al., 2004). Thus, complex systems are characterized as non-linear because the components that comprise them are constantly interacting with each other through a web of feedback loops (Anderson, 1999; Stacey, 1995). Thietart \& Forgues (1995, p.21-22) describe the non-linear nature of interactions in organizations, which give rise to emergent, unknowable futures:

Multiple organizational actors, with diverse agenda, inside and outside the organization, try to coordinate their actions to exchange information and to interact in other ways and they do all this in a dynamic manner, i.e. yesterday's action activates a reaction today which may lead to a new action tomorrow.

Emergence happens in complex systems in part, because they are sensitive to initial conditions; that is, a small fluctuation in one part of the system can bring unexpected changes to other parts of the system. The story of the flap of a butterfly's wings in one part of the world creating a storm in another part of the world (Lorenz, 1963) is often used to illustrate the concept that small fluctuations in some variables can have profound and unpredictable effects on other variables.

Maguire \& McKelvey (1999) argue that when organizations move away from stability and into the "region of complexity," adaptive tensions give rise to emergent self-organization. In fact, most argue that it is only as organizations move into far-from-equilibrium states that emergent ideas are possible, giving rise to innovation and creativity (Anderson, 1999; Chiles et al., 2004; McKelvey, 1999). This brief discussion of complexity theory with its central premise of emergent self-organization, challenges us to change the way we think about leadership (Marion \& Uhl-Bien, 2001) and abandon the notion that leaders create foreseeable futures. We turn now to a review of the traditional leadership literature whose basic assumption is that organizations and leaders face knowable futures.

\subsection{Leaders as controllers}

The traditional view of organizations is based on the idea that the world is knowable because it is a kind of mechanical system in which discernable forces and basic laws of motion are in operation (Capra, 1996; Stacey, 1995). From this view, organizations consist of highly prescribed rule sets, formalized control and hierarchical authority structures, which are intended to simplify the organization's ongoing operations and lead to simple, and welldefined and predictable responses to a changing, yet knowable world. Traditionally, organizations seek order and leaders are expected to achieve stability by reducing complexity through codification (Boisot \& Child, 1999), solving problems using reductionist rather than holistic thinking, understanding critical cause and effect linkages (Ashmos, Duchon, McDaniel, \& Huonker, 2002), and engaging in complex planning for a world they believe is predictable (Wheatley, 1999). From this view, leaders try to control the future by acting now to reduce complexity and uncertainty and directing followers towards highly prescribed future states.

The study of leadership has been an important part of traditional organizational science for decades, yet disappointing to many because of the proliferation of leadership theories with no universally accepted theoretical framework for understanding leadership. It is beyond the scope of this paper to review the entire literature on leadership (see Hunt, 1999) however, we summarize some of the major approaches to studying leadership in order to make the following point (Bass et al., 1987; Fiedler, 1967; House, 1971; Steers et al., 1996; Yukl, 1989). Regardless of the partic- 
ular theoretical approach, leadership has been viewed largely as a way of directing and controlling foreseeable organizational futures. Thus, leaders who are generally defined as those who exercise intentional influence over people to channel and facilitate collective tasks in order to achieve organizational goals (Yukl, 2002), create desired knowable future states through direction and control.

\subsubsection{Traits vs. behaviors}

Perhaps the oldest debate about leadership involves leadership traits versus leadership behaviors. In some of the earliest research on leadership, scholars sought to know what 'special' traits were associated with leader effectiveness at bringing about change and achieving organizational goals (Steers et al., 1996). Traits included physical, social, and mental ability and leaders were distinguished from subordinates because they gave directions that were then followed by subordinates. Later leadership theories focused on behaviors of successful leaders - what leaders actually do - to bring about change. In this line of research, the hope was to sort out the right combination of task orientation and people orientation in order to determine what made for successful leaders (Fleishman and Harris, 1962; Likert, 1961). Contingency theories of leadership (e.g. Fiedler, 1967) followed the trait and behavioral theories and suggested that situations determine which leadership trait or behavior is appropriate and effective in directing the organization.

\subsubsection{Styles}

Another area of inquiry in leadership research has been a focus on leadership style. The path-goal theory (House, 1971) suggested, for example, that the leader alters his/her style depending upon whether employees need clarity about goals and expectations, or about the path towards achieving the goals and expectations. Thus, the leader calculates what style of leading - instrumental, supportive, participative, or achievement-oriented - would most likely realize the organization's desired future state.

More recently, the literature on leadership style includes two distinct and contrasting styles commonly referred to as transformational and transactional. Someone using a transformational style motivates and influences followers to work for collective goals by going beyond current norms and inspiring subordinates to transcend their selfinterest for the sake of the organization. Leaders using this style provide persuasive symbols, images, and visions of the future to influence subordinates (Bass, 1985; Bass et al., 1987; Burns, 1978). A contrasting style, conventionally called transactional leadership, presents leaders as influencing employees primarily by providing material rewards in return for their efforts. Transactional leaders work within the established organizational framework (Bass, 1985; Burns, 1978) and help subordinates recognize role and task requirements to reach desired outcomes. A leader using a transactional style clarifies work to be accomplished, uses rewards as reinforcement, and intervenes when standards are not met.

The leadership style frameworks share in common with the trait and behavior theories of leadership the assumption that leaders actively create conditions to reach a well-articulated future state through planning, directing, organizing, and controlling (Marion and Uhl-Bien, 2001; Stacey, 1992; Wheatley, 1999). The traditional frameworks are deterministic, top-down, and assume an equilibrium end-state. Surprise and emergence are not prominent features of such models, and in fact are avoided. Thus, a complexity view of organizations, in which surprise and emergence are central features, provides insight into how leadership happens in dynamic situations.

\subsection{Leaders as enablers}

The complex system characteristics described above clarify how it is that novelty emerges in organizations yet raises significant questions about leadership in complex adaptive systems. Each of these characteristics makes it clear that, from a complexity view, leaders do not direct change or control future outcomes, as traditional leadership research suggests. If leaders cannot envision and predict the future state of a system, if they do not direct change in complex systems because it emerges from the interactions among people throughout the system, what, then, do leaders do?

Marion \& Uhl-Bien (2001) review the literature on complexity science and argue that complex leaders enable rather than control futures by cultivating conditions where others can produce innovations that lead to productive, and largely, unpredictable future states. They argue, "Leaders cannot control the future (e.g., determinism) because in complex systems such as organizations, unpredictable (and sometimes unexplainable) internal dynamics will determine future conditions" (Marion \& Uhl-Bien, 2001, p. 391). Thus, Marion \& Uhl-Bien (2001), as well as other complexity scientists (Maguire and McKelvey, 1999; Regine and Lewin, 2000), call for reconsideration of traditional ap- 
proaches to leadership. They suggest an alternative focus on leadership where leaders enable rather than control, where power derives from the leaders' ability "to allow" rather than to direct (Regine \& Lewin, 2000), and where people in the organization remain engaged and connected (Knowles, 2001).

Marion \& Uhl-Bien (2001) also argue that effective leaders recognize the importance of interactions, correlation, and unpredictability among ensembles or aggregates of individuals. Complex leaders enable interactions but they do not direct them. Instead, they allow them to emerge through engaging in non-linear processes (Regine \& Lewin, 2000). These interactions help facilitate "correlation," what Marion \& Uhl-Bien (2001) describe as the emergence of a common or shared understanding of the system, a recognizable pattern in organizational behavior. When leaders facilitate "correlation" they help others make sense out of what is happening; they give meaning to unfolding events.

In addition, complex leaders enable emergence by becoming catalysts for actions, and function as "tags" (Holland, 1995; Marion and Uhl-Bien, 2001). Tags enable or speed up specific behaviors by directing attention to what is important and providing meaning to events. Tags are important for understanding the role leaders can play in influencing their organizations. For example, Marion \& Uhl-Bien (2001, p. 398) describe the role that Martin Luther King, Jr. played in the civil rights movement: he "did not create the civil rights movement; rather he catalyzed its development." In other words, he was a tag for the civil rights movement.

The arguments of Marion \& Uhl-Bien (2001) are appealing and well-grounded in the theoretical framework of complexity science, but have not been established empirically. Our review of their work, the leadership literature, and the fundamental characteristics of complex adaptive systems led us to the following research question: How do leaders enable emergent, self-organization? In this research, we provide preliminary empirical support for the notion that in complex adaptive systems, successful leaders enable rather than direct the future. Specifically, we observed that leaders, as enablers, use the following mechanisms: disrupting exiting patterns, encouraging novelty, and making sense of the unfolding events for others.

\section{Methods}

We used a qualitative approach to observe the complex interactions and behaviors that characterize complex adaptive systems and their leaders. However, we did not begin originally with these intentions. Instead, we began our case study with a focus on reviewing the decision-making process at a local organization - Mission Church. ${ }^{1}$ This preamble study relied on an inductive approach, which is consistent with methodology used in similar research (Eisenhardt, 1989b; Isabella, 1990). Our initial review of decision-making processes ultimately became a study of continuous, radical change, which had started five years prior to our initial study (see Plowman et al., 2007). Findings from the study of radical change suggested that leadership was one of several factors contributing to the radical, and unintended organizational transformation at Mission Church. The present study extends the research from the previous study on radical change, and examines specifically the leadership behaviors within an organization that experienced a profound transformation, one initiated unexpectedly from the interaction of a few individuals in the system and not from the direction of the leaders. A brief description of the sample organization is below.

Formerly viewed as a "big-steeple" wealthy church, Mission Church is located downtown in the tourist center of a large city. For several decades, Mission Church had been in decline in spite of a four-year effort by the current energetic and charismatic co-pastors to turn the church around. Unexpectedly a few young people, out of boredom, decided to offer hot breakfasts to the homeless people who walked by the church on Sunday mornings. The breakfast idea took hold and ultimately led to a radical and unplanned shift in identity for the church, which became a highly visible voice for the city's homeless, establishing a 501 (c) (3) non-profit organization for acceptance of city grants, servicing several thousand homeless people a year, and serving 20,000 meals a year. In addition, other radical changes included assignment of full-time ministry with the homeless, hiring of a church nurse, psychologist, behavior specialist, and others to work with the church's homeless day center. Homeless people began joining the church, singing in the choir, and ushering at the major worship service. While many members left, new people, attracted to the church's ministry with the homeless, began joining the church, and the co-pastors became recognized as advocates for the city's poor. The fifty-year decline began to subside. Not without controversy, Mission Church became a centerpiece in the city's struggle with the issue of homelessness for 26,000 of its population. 


\subsection{Data collection}

Mission Church offered us the opportunity to examine in fine-grained detail, the actions of leaders who were actively engaged in a changing organization, but did not seem to be directing the change. Our data came from three sources: (1) open-ended interviews with 16 representatives from Mission Church - including the church co-pastors (i.e., leaders), congregation members, employees, and volunteers, (2) open-ended interviews with 6 representatives of the downtown community - including business leaders, city council members, and law enforcement officers, and (3) secondary sources such as newspaper articles, internal church documents, grant applications, church websites, and informal observations.

Semi-structured interviews with individual respondents represented the primary source of data. We conducted two sets of interviews. The first set of interviews happened on the church property and involved paid staff and volunteers of the church and its homeless Day Center. Respondents included two senior co-leaders of the church, the church business manager, church building manager, Day Center manager, director of food services, nurse, maintenance engineer, mental health director, five church volunteers, and two volunteers at the Day Center. We conducted a second set of interviews with representatives of the downtown community surrounding the church in order to discover the perceived impact of the church's homeless ministry on neighboring businesses. Respondents included a hotel manager, leader from the downtown business alliance, city council member, bank executive, property manager, and a police lieutenant. The interviews, which lasted about 60 minutes each, were taped and transcribed. Each interview was conducted by two members of the research team, with one member responsible primarily for conducting the interview and the other for taking notes. Immediately after the interview, the two researchers crosschecked facts and impressions. We followed Eisenhardt's (1989a) rules in that we: (1) developed detailed interview notes within 24 hours, (2) included all data from the interview, and (3) concluded each set of interview notes with the researchers' overall impressions.

Interviews with members internal to Mission Church were organized into four sections: respondent's background, his/her role and relationship to the church and/or Day Center; purpose, mission, and uniqueness of the church and Day Center; church and Day Center decision processes; and finally, challenges and opportunities facing both the church and the Day Center. The interview guide for interviewees external to Mission Church was comprised of five sections: respondent's background and responsibilities; impact of Mission Church's homeless ministry on the respondent's organization; the nature of the relationships among downtown organizations; a proposed city ordinance regarding homeless people; and finally, respondent's feedback to the church regarding its homeless ministry. At the end of each interview, we asked informants to share any additional information they felt was relevant.

Members of the research team reviewed 34 newspaper articles that contained information about the church and/or its leadership. We reviewed internal church documents, church reports, the Church's website, websites of other local service providers to the homeless, grant applications, and other materials as available. We also made informal observations during site visits, while waiting for interviews, and eating in the restaurant located in the church. Finally, we observed two monthly Board of Directors meetings for the church's non-profit spin-off as well as a meeting of church leaders, downtown residents and city officials, and took extensive notes that we used for later reference.

\subsection{Data analysis}

Members of the research team created a narrative account or story of the impact that leadership had on the transformation at Mission Church. This analytic approach is appropriate for organizing longitudinal data, especially when based on a single case of abundant information (Langley, 1999). These stories were developed based on

each researcher's review, understanding, and text analyses of interviews, observations, and newspaper articles in an effort to make sense of the data (Miles \& Huberman, 1994). Reviewing and discussing the stories while returning to the literature on leadership and complexity science ultimately led to the framework we used.

We reviewed each interview transcript sentence by sentence and identified all quotations associated with the overall theme of leadership. We then coded the leadership quotations into three leadership categories: 1) leader is part of destabilizing things, 2) leader encourages innovation, and 3) leader is sensemaker. These categories and definitions emerged as key elements of leadership following our overall review of the leadership quotations and our intimate prior experience with the impact of leadership in emergent radical change. These category definitions were used for coding purposes once definitional consensus was achieved. 
Two authors were responsible for coding quotations from a single interview transcript - i.e., a first and second coder. We employed this dual-coder method for each of the 22 interview transcripts. Review and discussion between the first and second coders continued until the two coders reached $100 \%$ agreement on the quotations to include within each of the leadership categories. This process resulted in 167 quotations about leadership.

Triangulation of data provided us confidence in the validity of our study and data collection processes. Wherever possible, we triangulated data obtained from interviews, observations, documents, and other secondary sources. Our reporting includes only data that were substantiated across multiple information sources. We also triangulated data using multiple methods of analysis, such as narrative analysis, and visual mapping. The two leaders at Mission Church reviewed our final analysis, confirmed what we had found, and offered additional insights and details. This review by the organizational leaders provided a final check on the accuracy of our findings.

\section{How do leaders enable emergent self-organization?}

\subsection{Case background}

Mission Church underwent a radical transformation from a dying church with nothing unique about it to one that people throughout the city came to recognize for its ministry with the city's homeless. The church partners with the city for providing services to the homeless and regularly receives city grants that help support the ministry, while declaring in its mission, "It's not just about food and hospitality; it's about changing lives." The Church, downtown business leaders, and Police Department representatives increasingly work together on issues related to the homeless. Church members regularly meet with downtown resident associations and attend city council meetings advocating for the homeless and recently staged a protest of the city's new ordinances that outlaw vagrancy. The decline in church membership has stopped as new people and families are coming to church, attracted by the church's unique identity. The average age of the congregation is considerably younger now and it is much more racially diverse than it once was. The leaders of the church did not envision this change or initiate it, but at the same time played a critical role in its emergence.

We returned to our notes to try to understand exactly what the leaders' roles were in bringing about the transformation if they did not originate the idea, construct the vision, and inspire others to follow. The results of our qualitative analysis revealed three mechanisms that the leaders used as enablers of emergent self-organization: (1) disrupting existing patterns, (2) encouraging novelty, and (3) sensemaking. We describe these mechanisms below and in Table 1.

Table 1. The role of leaders as enablers in emergent, self-organization

\begin{tabular}{|c|c|c|c|}
\hline $\begin{array}{l}\text { Mechanisms used } \\
\text { by complex leaders }\end{array}$ & $\begin{array}{l}\text { Actions taken } \\
\text { by complex leaders }\end{array}$ & Propositions & Managerial implication \\
\hline Disrupt existing patterns & $\begin{array}{l}\text { - Create and highlight con- } \\
\text { flict } \\
\text { - Acknowledge uncertainty }\end{array}$ & $\begin{array}{l}\text { Complex leaders enable emergent futures by dis- } \\
\text { rupting patterns through the use of conflict and } \\
\text { uncertainty; whereas traditional leaders create } \\
\text { knowable futures by minimizing conflict and } \\
\text { eliminating uncertainty. }\end{array}$ & $\begin{array}{l}\text { - Leaders destabilize rather } \\
\text { than stabilize organizations. }\end{array}$ \\
\hline Encourage novelty & $\begin{array}{l}\text { - Establish simple rules } \\
\text { - Encourage "swarm like" } \\
\text { behaviors } \\
\text { - Promote non-linear } \\
\text { interactions }\end{array}$ & $\begin{array}{l}\text { Complex leaders become enablers of emergent, } \\
\text { self-organization by encouraging innovation } \\
\text { through simple rules, non-linear interactions, } \\
\text { and swarm behaviors; whereas traditional lead- } \\
\text { ers operate as controllers by leading through } \\
\text { command and control. }\end{array}$ & $\begin{array}{l}\text { - Leaders encourage innova- } \\
\text { tion rather than innovate. }\end{array}$ \\
\hline Act as sensemakers & $\begin{array}{l}\text { - Create correlation through } \\
\text { language } \\
\text { - Accept the role of 'tag' }\end{array}$ & $\begin{array}{l}\text { Complex leaders become enablers of emergent, } \\
\text { self-organization by being sensemakers through } \\
\text { correlation and becoming tags; whereas tradi- } \\
\text { tional leaders operate as controllers by directing } \\
\text { order. }\end{array}$ & $\begin{array}{l}\text { - Leaders interpret emerg- } \\
\text { ing events rather than direct } \\
\text { events. } \\
\text { - Leaders manage words } \\
\text { rather than manage people. }\end{array}$ \\
\hline
\end{tabular}




\subsection{Disrupting existing patterns}

According to the complexity theory, the kind of emergent transformation that Mission Church experienced is possible under conditions of disequilibrium, which occurs when destabilizing forces move organizations towards greater non-linearity and instability (Prigogine and Stengers, 1984; Stacey, 1995). In a recent study, Plowman et al. (2007) observed multiple contextual factors or "tension gradients" (McKelvey, 1999) that create instability and move organizations towards disequilibrium. A complexity theory perspective suggests that leaders play a role in destabilizing systems by disrupting existing processes or patterns of behavior, thereby pushing the systems towards chaos (Regine \& Lewin, 2000) or regions of complexity (Maguire \& McKelvey, 1999). Our findings suggest that the leaders at Mission Church destabilized the organization by (1) creating and highlighting conflict, and (2) embracing uncertainty.

\subsubsection{Creating and surfacing conflict}

Our interview findings suggest that conflict permeated Mission Church and that the church's leaders were often in the center of the conflict. Informants told us that prior to the radical shift in the church's mission, the leaders took several actions that created controversy. They welcomed homosexuals to the congregation, and experimented with alternative music and styles of worship. They unlocked the doors of the church during the week making it accessible to everyone. They made unpopular personnel changes and invited controversial speakers. Most of these actions were part of their somewhat frenetic and ultimately unsuccessful efforts to find a solution to the church's decline problem. Once the Sunday morning breakfasts were well underway and had amplified into a full-blown ministry with the homeless, the conflict intensified. Many long-time members left the church, in part because of the growing presence of homeless people in the church. One respondent described some results of this internal conflict "when homeless people started coming in it drove other (members) away."

Business leaders outside Mission Church also described the conflict between the local business community and the Church's new ministry. One respondent said:

"I believe that the leadership ... took on a project that was going to impact an entire neighborhood. They made their decision and it was 'so be it ... this is what we're going to do and forget about you'. I think that was the wrong attitude to have and therefore, I think that ... they need to reach out to their neighbors and find out first ... how it is going to impact them."

One church volunteer also conveyed the impact of the church's controversial stance with local businesses - "the (local) merchants ... are less receptive to (the leader because) it's that tension between what we're doing and how it is not consonant with capitalism." The co-leaders at Mission Church initiated some conflict and surfaced other conflicts, instead of employing the more traditional leadership focus of attempting to minimize or eliminate it.

The leaders not only initiated conflict, but they also used a variety of media techniques to bring visibility to the emerging new future at the church, which introduced further disruptions into the system by highlighting and surfacing more conflict. For example, the co-leaders used print, broadcast, and outdoor media to disseminate the Church's changing ministry and its vision of unconditional love and justice in action. During a recent two-year period, 34 newspaper articles highlighted Mission Church and its ministry to the homeless and other marginalized. In addition, the local news stations frequently interviewed the church leaders oftentimes in reference to the city's homeless problem. Billboards in the city echoed the church's vision and mission with phrases such as "Hell and Judgment not included" and signs posted inside the church proclaim "we've been called non-traditional, progressive even radical and here we thought we were just doing what a church was supposed to do." The church's struggle to find a vision and its emerging controversial identity became public as the communication mechanisms made individuals both inside and outside the church aware that things were changing. Although the intent of these efforts was directed at information sharing, another outcome was further system instability. Use of these public forums encouraged new agents into the system, highlighted the conflicts among existing agents, and helped push the system further from equilibrium. In doing so, the leaders created and surfaced conflict that added instability into the system, thereby enabling emergent, self-organization.

\subsubsection{Embracing uncertainty}

Finally, the leaders at Mission Church refused to back away from the uncertainties facing the church and actually forced the congregation to face its troubling future. At the time of our study, the leaders commented that 
they had tried every conventional approach to revitalizing the church for four years, but to no avail. As one informant told us "[The leaders] came and tried to change things, but it was like moving a battleship; they couldn't change it." Although unsuccessful in their initiatives at change for four years, the leaders talked openly about the church's ongoing decline and the uncertainty facing the church. For example, they encouraged everyone in the church to read and engage in discussions of a controversial book about how "unhealthy" churches need to kick their bad habits and address the cause of their sickness. Their openness and active engagement in conversations about the status of the church and its unlikely future put information and opinions into the system that seemed to destabilize it further, making it more likely that a new order could emerge. Our interview findings suggested that the leaders were not afraid to raise questions and try new things (See Table 2.). These leader-initiated conversations placed stress on the historically traditional "silk-stockings" church and pushed the system into the region of complexity.

When we contrast the style of leadership found at Mission Church with traditional leadership theories, we find that the leaders of Mission Church exhibited many of the characteristics of complex leaders as described by Marion \& Uhl-Bien (2001). The leaders did not shy away from unpredictable or unexplainable outcomes. Rather, they embraced the unknowable, and actually introduced system instability through organizational conflict, system disruptions, and open conversations about the church's uncertain future. Our study revealed that the leaders contributed to the organization's instability by disrupting existing patterns, which then made it much more likely that emergent ideas would bubble up from within the organization.

Table 2. Evidence of the role of leaders as enablers

\begin{tabular}{|c|c|}
\hline Source & Quote \\
\hline Church staff & $\begin{array}{l}\text { The leaders turned this world upside down, in a good way. They changed the way we worship, they brought in new } \\
\text { styles of music, they opened the doors to the people on the streets. }\end{array}$ \\
\hline $\begin{array}{l}\text { Church } \\
\text { member }\end{array}$ & $\begin{array}{l}\text { But the pastor came fired up saying 'gosh this is it we can do this' and in his usual way just came in and declared that } \\
\text { that's what our vision is... and that really rubbed a lot of people wrong. }\end{array}$ \\
\hline Church staff & $\begin{array}{l}\text { We try not to have so many rules and regulations that it forbids anybody to be serviced or get those basic needs that } \\
\text { people need to get through the day. }\end{array}$ \\
\hline \multicolumn{2}{|c|}{ Leaders encourage innovation } \\
\hline $\begin{array}{l}\text { Church } \\
\text { volunteer }\end{array}$ & $\begin{array}{l}\text { There was a big idea about the church that was being debated. There was a lot of space on the third floor that is not be- } \\
\text { ing used and the leader stood up and said 'hey, we're not using this, we are not being faithful stewards of all that } \\
\text { we've been given' and challenged the people to come up with an idea. }\end{array}$ \\
\hline $\begin{array}{l}\text { Church } \\
\text { member }\end{array}$ & $\begin{array}{l}\text { It used to be that if you had you took it to the committee and maybe two years later you might get your idea approved. } \\
\text { Now its pretty much encouraged, that if you've got an idea, go get yourself a committee and do that. }\end{array}$ \\
\hline $\begin{array}{l}\text { Church } \\
\text { volunteer }\end{array}$ & $\begin{array}{l}\text { In fact the leader's mantra was trying to grow a congregation that would be responsible for their own behavior; - that } \\
\text { the congregation would hold itself and each other responsible for bad behavior, removing the pastor from the triangu- } \\
\text { lation of being the judge and the mediator between people. }\end{array}$ \\
\hline \multicolumn{2}{|c|}{ Leaders are sensemakers } \\
\hline $\begin{array}{l}\text { Church } \\
\text { member }\end{array}$ & $\begin{array}{l}\text { The leader decided to get involved and he just jumped in and it was his natural gift because he's got his gift of lead- } \\
\text { ership and people skills it just. That's when it really evolved, because up to then it was the breakfast and volunteers } \\
\text { were being fulfilled. we were fulfilling a need but that was about it, but right after [the leader] became involved, ev- } \\
\text { erything changed. }\end{array}$ \\
\hline Newspaper & Church leader has emerged as a spokesman for the city's 26,000-plus homeless people \\
\hline
\end{tabular}




\subsection{Encouraging novelty}

In contrast to traditional prescriptions in the literature for leaders to have a vision and articulate it clearly (Kotter, 1996), the successful transformation of Mission Church resulted ultimately from the innovative action taken by a handful of young adults - not the leaders - without any formal church approval or budget authority. The pastors jokingly told us they wish they could take credit for the original breakfast idea, but they could not. When presented with the Sunday morning café idea, which emerged from the interaction of a group of young people over dinner one night, the leaders gave permission to proceed to try the idea, but had little involvement in the program initially. As one informant told us, "The café was just like a little small idea that just got out of hand; you know... it's like a grass fire." Although the Sunday morning breakfasts that started without the church's leaders were the impetus of an unexpected, radical identity change for the church, there was a clear sense that the leaders were deeply engaged in the transformation of the organization.

What we observed was that in the early years the leaders were using, unintentionally, a paradoxical leadership approach. On the one hand, the leaders tried to do what they thought 'good' leaders do - articulate a vision and get others to buy into it. On the other hand, with something of a laissez faire attitude, they encouraged church members who had an interest in a particular program or ministry to get together with others sharing that interest and try it (See Table 2). Upon closer examination of this somewhat paradoxical leadership style that emphasized generating novelty, we observed three phenomena at work in encouraging innovation: (1) the establishment of a few simple rules, (2) swarm behavior of membership and staff, and (3) the promotion of non-linear interactions and emotional connections among people.

\subsubsection{Simple rules}

Throughout our interviews and observations, we continually heard the leaders, staff, church members, and others refer to the question, "What would Jesus do?" The leaders and church members used this question repeatedly to explain their position, for example, in allowing homeless people (in the later years) to sleep on the church's property, in spite of city ordinances outlawing camping. In reference to the departure of some church members from Mission Church because of its ministry with the homeless, one church member told a newspaper reporter, "If they separate from a church that's trying to show unconditional love as Jesus taught us, then it's become just words for them." One member told us his story of complaining to one of the leaders that he wished the homeless people would express more gratitude for his volunteer services. The leader reminded him that Jesus would probably not be interested in whether there was a lot of reciprocation for the care that he was providing to the homeless. Members of our research team attended meetings of city government officials, church leaders and members, downtown business residents and business officials regarding the crowds of homeless people using the church property to sleep, and witnessed the leader say, "I realize that this church is seen as stubborn because we just don't think Jesus would turn these people away." What we saw was a tenacious rigidity about the principle and complete flexibility about how to go about carrying out the principle.

\subsubsection{Swarm-like behavior}

A dominant means of encouraging innovation was the presence of "swarm intelligence" (Bonabeau \& Meyer, 2001) among members of the congregation. Social insects such as bees, termites, and ants work without supervision, and can achieve remarkable accomplishments of organization in seemingly chaotic fashion.

Termites construct their beautifully intricate colonial dwellings through processes that look anything but organized. Yet, out of the activities of termite construction gangs, that form and disperse in apparently disorganized patterns, there emerge coherently structured pillared halls and passageways, complete with air conditioning, that accommodate thousands of inhabitants. (Goodwin, 2000, p. 42)

"Swarm intelligence" is observable in organizations as well when complex collective behavior emerges from individuals who follow simple rules. People in organizations can solve difficult problems (like how to turn around a dying church) even though each local interaction might, itself, be very simple (like asking oneself what would Jesus do about homeless people who want to come inside the church). Some of the descriptions we heard of the way in which the breakfasts, which ultimately transformed the church, got started included considerable disorganization. The Sunday breakfasts amplified into a larger and more complex program the day a physician member of the congregation unexpectedly set up a table to see patients during the breakfasts. (This ultimately resulted in the estab- 
lishment of full-scale medical, dental, and optometry clinics). The description of that first day seemed anything but thought out and organized as a physician church member reported:

I thought, well what the heck, it doesn't hurt to carry my bag in. So I had two chairs next to a table and set up right in the midst of all this stuff. [Someone] had a microphone and was trying to herd the folks around and he started saying "the doc is in, if you want to see the doc." And we were literally right in the middle of all this.

A local interaction between a doctor, asking himself the question, "What would Jesus do," and people who showed up for breakfast, led to a complex collective pattern of behavior at Mission Church. A simple rule and a local, unsupervised interaction led ultimately to a complex ministry that included providing not just food, but medical, dental, and other services to thousands of homeless people each year.

\subsubsection{Non-linear interactions}

A final means of encouraging innovation was that the leaders also encouraged connections among people, in particular, non-linear, emotional connections. These connections are essential for the emergence of novelty (Dutton \& Heaphy, 2003). According to Regine \& Lewin (2000, p. 12), "Anything that enhances the interactions will enhance the potential creativity and adaptability of the system." The swarm-like behavior was facilitated in part by the way information was shared widely among members of the church and its leaders through non-linear interactions. For example, for four years prior to the start of the breakfasts, the pastors had emphasized small groups in the church, as a way of creating more points of entry for new people to the church. They would invite groups of visitors and a few members to their home for dinner. They started a weekly women's reading group, informal sports activities, and dance classes. While the hope was that these small groups would attract new people to the church, it seems that a major impact of these small groups was establishing or increasing connections among people and opportunities for interaction. Complexity theory suggests that, when agents come together to share information and respond to information they have been given, novelty is possible (Regine \& Lewin, 2000). What the leaders did not do was use the pulpit to hand down decisions about what was to be done. Rather, they used the pulpit to remind people of the values and the principals and then challenge them to respond as they saw fit.

The idea for the breakfasts emerged out of conversations among young people over dinner. The dinner was hosted at the leaders' home, as had been many similar dinners with other people - with the purpose of getting to know one another. The leaders at Mission Church encouraged innovation through a few simple rules, swarm intelligence that led to complex patterns of collective actions as well as non-linear interactions and emotional connections among people.

\subsection{Sensemaking}

Our study also revealed that the leaders aided the transformation of the organization by acting as sensemakers. Sensemaking is the process by which individuals "construct meaningful explanations for situations and their experiences within those situations" (Gioia, 1986, p. 61). Leaders as sensemakers are important as previous research has found top managers' ability to scan the environment and interpret issues influence decision-making and strategic change in organizations (Gioia and Thomas, 1996; Smircich and Stubbart, 1985; Thomas et al., 1993). We found evidence that the leaders at Mission Church enabled change by making sense of the emerging change in the organization (Weick \& Quinn, 1999) and giving meaning to unfolding events (See Table 2). The leaders were able to recognize that the breakfasts and ministry to the homeless were energizing and mobilizing the congregation in stunning ways. They also began to recognize that the emergent ministry with the homeless was possibly the catalyst needed to turn the church around.

Weick (1993, p. 635) argues "the basic idea of sensemaking is that reality is an ongoing accomplishment that emerges from efforts to create order and make retrospective sense of what occurs." Leaders in complex organizations play an important role in giving meaning to what is happening in organizations, telling others how things might be rather than how they are (Weick, 1995). This sensemaking role is particularly important in dynamic systems where change is emerging through actions not necessarily intended by the leaders. Based on Weick \& Quinn's (1999) description of change agents as sensemakers, we saw the leaders of Mission Church involved in two sensemaking activities: (1) assuming the role of a 'tag,' and (2) creating correlation through language. 


\subsubsection{Assume the role of 'tag'}

Complex leaders enable emergence by becoming catalysts for actions and assuming the role of "tags" (Holland, 1995; Marion and Uhl-Bien, 2001). Tags enable specific behaviors by directing attention to what is important, and what things mean. A leader becomes a tag when others recognize them as a symbolic reference for their corresponding message. The leaders at Mission Church did not direct or did not create the homeless issue in their church and/or city. However, they became tags, subsequent to their homeless ministry involvement, when they catalyzed the community-wide attention to the social issues concerning the homeless.

According to informants, it was a year or so after the beginning of the Sunday morning breakfasts that the leaders began to recognize the potential redirection that was possible for the church through the Sunday morning breakfasts. Up to that point, the leaders had been minimally involved in the breakfasts, largely because the breakfasts occurred at the same time as the early worship service, which required the leaders' attendance. However, that changed when the leaders decided it was inefficient to use two pastors in a small worship service to the "silk-stockings" folks while 200 homeless people, in need of pastoral care, were having breakfast downstairs. From that point on, the Sunday morning breakfasts became a critical part of the church's ministry and the radical shift in organizational identity accelerated. One informant reported to us the leader's decision to become more involved in the Sunday morning breakfasts:

"[The leader's] exact words were "that café needs a kick in the pants" and those were his exact words and so I thought okay and once that whole transition was made from getting two pastors out of preaching to ten people at 9 o'clock and go serve the 200 who were sitting right below you, you know, that was huge. I think that was huge.... From that moment on when [the leader] decided to get involved.... that's when it really evolved."

When the leaders began to see the breakfasts in a new light, the Sunday morning program took on a new meaning and its shape changed as the leaders catalyzed and re-framed the church's purpose. The leaders were important in recognizing the nature of the change that had emerged, and they gave new meaning to it by redefining the leader's role in relation to the breakfasts.

Weick \& Quinn (1999) suggest that leaders give meaning to emergent events by re-framing them. As the church's identity began to emerge in the direction of ministering to people marginalized by society, the leaders began to articulate the Biblical support for what was happening and took on a symbolic role for serving these people. The leaders compared the marginalized people outside the doors of Mission Church to the marginalized people of Biblical times: "women, tax collectors, prostitutes, those suffering from mental illness, the mixed race Samaritans, Roman government officials and the poor-just to name a few." These illustrations crystallized for church members the importance of the changes that were occurring, even if it was unclear exactly where the changes would lead.

The leaders accepted the role of tag as they enabled specific behaviors, such as homeless ministry, by directing and re-framing attention as to how important these behaviors are to the church. The leaders, once involved, catapulted the Sunday morning breakfasts into a social movement of homeless service. Through these actions, the leaders rose as tags of the homeless issue for church members and for the city as a whole and become symbols and catalysts for actions regarding the treatment of homeless individuals.

\subsubsection{Create correlation through language}

Leaders as sensemakers also make changes salient for organizational members, that is, they label behaviors in a way that helps provide coherence, what Marion \& Uhl-Bien (2001) call correlation. In addition, complex leaders, especially those that play the role of a "tag," can use language to foster correlation (Marion \& Uhl-Bien, 2001). With language as a medium, it is possible for leaders to "establish the identity of the objects, events, and actors that constitute their social environment" (Robichaud, Giroux, \& Taylor, 2004, p. 630). Recent research suggests that the language of leaders is a powerful organizational tool for articulating meaning and collective action (Fiol, 2002). In regards to the organizational vision, Conger (1991, p. 43) argues, "the language of leadership plays a vital role in its acceptance and accomplishment." The language of leaders can help to crystallize the image of the organization (Duimering \& Safayeni, 1998) and the identity of the organization (Robichaud et al., 2004). Effective leaders are those with the ability to energize collective action through the use of words that are expressive and inspirational (Conger, 1991).

When leaders explain and repeat specific language to their organization, they foster the development of a shared understanding (correlation) and become catalysts for specific actions (tags). Throughout our interviews, we heard many of the same phrases and language, which we attributed to the leaders of Mission Church. The leaders developed a common language within their church that provided meaning and correlation within church members and staff, and that helped catapult the church's focus on homeless ministry. 
The church's mission statement set by the leaders is "unconditional love and justice in action." One church leader explained, "The purpose of the Church actually is about God. I think God is really interested in acts of charity and acts of justice, both. ... And acts of charity and justice are just part of God's agenda." In addition, the church leaders often used the terms transformation, respect, and dignity. For example, the church's co-leader told us, "it was my notion that we are all about respecting dignity for all persons and in my notion, I thought that ... the rules [in the Day Center] don't help that. That the minimum amount of rules was the best witness we could get to human transformation and respect and dignity for all people." Church members and staff frequently used similar language (See examples in Table 2).

The leaders of Mission Church used this specific language to communicate the Church's vision and mission. In doing so, correlation occurred. Through use of such words as transformation, respect, dignity, love, and justice, the leaders created a shared understanding of who the church is. The number of times the interviewees repeated specific terms provided evidence of correlation. For example, 'transformation' was repeated 60 times, 'justice' 22 times, 'dignity' and 'love' were both repeated 21 times, and 'respect' was repeated 17 times. Fourteen of the sixteen individuals from within the church used these key words during their interview. One church member expressed the importance of the leaders' use of language by telling us "all of these words become a reflection of what they are trying to say. They repeat them so that occasionally somebody will hear them in a different way and experience the transformation, and if by virtue of being so consistent, sets the agenda for the vision basically." Further comments from informants provided evidence of the powerful way in which the leaders used language:

A church congregant said, "One reason I belong to this church is that it preaches unconditional love - and we're talking about everyone."

We [the church leaders] became convinced that the one thing we can do in terms of making a difference is reminding people that everybody needs to be treated with dignity and respect. We believe that everybody should receive that, whether they're liars or dope addicts, or crack-heads, it really doesn't matter.

[The leader] delivers a message of inclusiveness and respect and dignity for all, a message carried by members, who, even after many affluent and Anglo families left, chose to stay (newspaper article).

By using a consistent language, the church leaders gave meaning to the changes underway at Mission Church. The careful use of language provided a consistent means to help transform lives, to treat people with respect and dignity, and to provide unconditional love and justice for all persons. The leaders acted as sensemakers by providing meaning to the emerging events within the church by assuming the role of a tag and using language to create correlation.

\section{Discussion}

The characteristics of complex systems, whose central feature is emergent, self-organizing behavior, raise significant questions about the role of leadership in such systems. Traditional theories of leadership focus on the leader's role in determining future desired states and directing organizational action to achieve those desired states. However, complexity science suggests that future desired states are unknown because they emerge from the ongoing interactions and self-organizing of agents within the system. In this research, we examined empirically the role of leadership in self-organizing systems. We agree with Marion \& Uhl-Bien (2001) that traditional theories of leadership need to be re-visited in light of more recent understandings of organizational behavior offered by complexity science. Their notion that leaders enable rather than direct change is appealing and we offer some initial empirical support in this qualitative study of leaders as enablers.

From our earlier study of emergent radical change (Plowman et al., 2007), we observed an organization that underwent radical transformation, which emerged from the interactions of a few people within the organization. These people were not the leaders of the organization and they acted from no official role or authority when they started the Sunday morning breakfasts that ultimately led to a shift in identity from a "silk and stockings" church to one focused on a ministry with the marginalized, in particular, the homeless. The leaders at Mission Church played a key role in the change that occurred, not by specifying it or directing it but by creating conditions that allowed for the emergence of such change. We observed how the leaders disrupted existing patterns of behavior by introducing or by openly addressing conflicts that arose. We also observed how the leaders encouraged novelty yet tenaciously adhered to simple rules - what would Jesus do, and unconditional love - that then freed others to create inno- 
vations. The leaders at Mission Church spent a lot of time making sense of the unfolding changes and helped give meaning to what was happening. They could link contemporary marginalized people to those of Biblical times, making more salient the change that was unfolding. Finally, we observed a skillful use of language that helped facilitate collective understanding and amplified some of the changes that were emerging. These findings offer the following implications for managers.

First, leaders in complex systems destabilize rather than stabilize the organization. This means that rather than specify a future desired state and alter the structure of the organization to achieve that desired state, leaders push the organization towards disequilibrium by introducing uncertainty and by visibly addressing conflict. Because it is only in a state of instability that novelty can emerge, effective leaders of complex systems create disruptions that encourage emergent self-organizing. While the leaders in our study created and encouraged disruptions in existing patterns of behavior, they also provided some order by interpreting and giving meaning to the actions that emerged from the self-organization. Marion \& Uhl-Bien (2001) called this providing "correlation." Second, leaders in complex systems encourage innovation rather than innovate. By encouraging non-linear interactions, leaders encourage others to be innovative, rather than assume all the responsibility for the innovative ideas. At Mission Church, the leaders had tried for several years to offer up innovations for turning the church around, but it was only when the innovation emerged from the interactions of a small group of individuals near the bottom of the organization, that an innovation finally began to take hold. Third, leaders interpret change rather than create change. Our findings suggest that leaders play an important role in giving meaning to what is happening, labeling the emergent change, and changing what it is that people talk about in the organization. As the radical shift in identity began to emerge at Mission Church, the leaders spent less time talking about how to turn around a dying church and more time talking about what it means to offer unconditional love and justice in action. Finally, our finding about the use of language suggests that leaders manage words rather than manage people. Effective leaders are intentional about the language they use to help people understand what is happening in the organization.

One of the unique features of the organization we studied was that two people shared the top leadership role. The co-leaders had different management styles and in fact at times seemed to offer the organization what Maguire \& McKelvey (1999) called "both Old and New Science." In other words, organizations probably need some parts to be stabilized so that the creative innovators can work around them. One informant described how the two leaders differed from one another - one was the cerebral type and the other was the giant Labrador. The leaders themselves would be the first to say that one is more comfortable with rules and procedures than the other is. It is possible that at Mission Church the push towards instability counteracted the push towards stability because of differences in style of the two leaders, keeping the system from swirling into complete chaos. While not at all common in most organizations, the idea of co-leaders has some appeal. It may be that co-CEO's, for example, is a more complex approach to leadership that merits consideration in complex systems.

This study is not without limitations. For example, although case studies offer fine-grained detail of organizational phenomenon, they are also limited in their approach. Some concern over the generalizability of our findings exists. Our research relied on a single qualitative study as the foundation for the theoretical propositions offered (See Table 1). In addition, Mission Church functioned as a non-profit organization. Thus, obtained findings may not apply equally to profit-seeking organizations. Replication of this work in profit-seeking organizations may prove insightful. We have generated propositions that we hope will be tested in future research with a larger group of organizations. Our findings also suggest the following two areas of future research.

First, McKelvey \& Lichtenstein (in press) suggest that emergence occurs in increasingly complex stages and Plowman et al. (2007) found some support for this idea. Learning more about the role of leadership at each stage of emergence will be important in furthering our understanding of leaders as enablers. For example, is the role of enabler more complex at one stage of emergence than at another? If so, what does that mean? How do differing levels of complex leadership present themselves in organizations? These questions warrant further research attention.

In our study, the emergent self-organizing behavior led to a successful transformation of the organization and we observed leader behaviors that seemed to enable this successful emergence. An equally important area of study is to examine those emergent surprises that lead to failure rather than success. Are there differences in the way leaders enable emergence that contribute to failures rather than successes? Our findings suggest that if leaders push the system too far into chaos, do not pay attention to the non-linear interactions, fail to provide meaning to the changes that are happening, and do not use language effectively, that the emergent innovation will likely fail. However, that may not be the case. Researchers need to give attention to successful versus unsuccessful emergence and the associated leadership practices. 
We began this study by wondering what the role of leadership is if emergence and self-organization are fundamental characteristics of organizations. What we see from our study is that leadership, while different from traditional perspectives, is still essential. Echoing Gilda Radner, it seems that leaders help organizations take the moment and make the best of it, without knowing what is going to happen next.

Acknowledgments - We thank Dennis Duchon for his helpful comments on earlier versions of this paper and we are indebted to Mary Helen Villarreal for her help in transcribing lengthy interviews. We also thank the anonymous reviewers for The Leadership Quarterly as well as Russ Marion and Mary Uhl-Bien for their valuable contributions to this paper.

\section{References}

Anderson, 1999 • R. Anderson, Complexity theory and organization science, Organization Science 10 (3) (1999), pp. 216-232.

Ashby, 1962 • W. Ashby, Principles of the self-organizing system. In: H. Von Foerster and G. Zopf, Editors, Principles of self-organization: Transaction of the University of Illinois Symposium, Pergamon Press, London (1962), pp. 255-278.

Ashmos et al., 2002 - D. P. Ashmos, D. Duchon, R. R. McDaniel, and J. W. Huonker, What a mess! Participation as a simple managerial rule to 'complexify' organizations, Journal of Management Studies 39 (2) (2002), pp. 189-206.

Ashmos and Huber, 1987 - D. P. Ashmos and G. P. Huber, The systems paradigm in organization theory: Correcting the record and suggesting the future, Academy of Management Review 12 (4) (1987), pp. 607-621.

Bass, 1985 • B. M. Bass, Leadership and performance beyond expectations, Free Press, New York (1985).

Bass et al., 1987 - B. M. Bass, B. J. Avolio, and L. Goodheim, Biography and the assessment of transformational leadership at the world-class level, Journal of Management 13 (1) (1987), pp. 7-19.

Boisot and Child, 1999 - M. Boisot and J. Child, Organizations as adaptive systems in complex environments: The case of china, Organization Science: A Journal of the Institute of Management Sciences 10 (3) (1999), pp. 237-252.

Bonabeau and Meyer, 2001 - E. Bonabeau and C. Meyer, Swarm intelligence: A whole new way to think about business, Harvard Business Review 79 (5) (2001), pp. 106-114.

Burns, 1978 • J. M. Burns, Leadership, Harper \& Row, New York (1978).

Capra, 1996 • F. Capra, The web of life, Anchor Books Doubleday, New York (1996).

Chiles et al., 2004 $\bullet$ T. Chiles, A. Meyer, and T. Hench, Organizational emergence: The origin and transformation of Branson, Missouri's musical theaters, Organization Science 15 (5) (2004), pp. 499-519.

Collins, 2001 • J. Collins, Level 5 leadership: The triumph of humility and fierce resolve, Harvard Business Review 79 (1) (2001), pp. 66-76.

Conger, 1991 - J. Conger, Inspiring others: The language of leadership, Academy of Management Executive 5 (1) (1991), pp. 31-45.

Duimering and Safayeni, $1998 \cdot$ P. R. Duimering and F. Safayeni, The role of language and formal structure in the construction and maintenance of organizational images, International Studies of Management and Organization 28 (3) (1998), pp. 57-85.

Dutton and Heaphy, 2003 • J. Dutton and E. Heaphy, The power of high-quality connections. In: K. Cameron, J. Dutton and R. Quinn, Editors, Positive organizational scholarship., Berrett-Koehler, San Francisco (2003).

Eisenhardt, 1989a - K. M. Eisenhardt, Building theories from case study research, Academy of Management Review 14 (1989), pp. $532-550$.

Eisenhardt, 1989b - K. M. Eisenhardt, Making fast strategic decisions in high-velocity environments, Academy of Management Journal 32 (3) (1989), pp. 543-576.

Fiedler, 1967 • F. E. Fiedler, A theory of effective leadership effectiveness, McGraw-Hill, New York (1967).

Fiol, 2002 - C. M. Fiol, Capitalizing on paradox: The role of language in transforming organizational identities, Organization Science 13 (6) (2002), pp. 653-666.

Fleishman and Harris, 1962 - E. Fleishman and F. Harris, Patterns of leadership behavior related to employee grievances and turnover, Personnel Psychology 15 (1962), pp. 43-56.

Gioia, 1986 - Gioia, D. A. (1986). Symbols, scripts, and sensemaking: Creating meaning in the organizational experience. In H. P. Sims, Jr., D. A. Gioia, and associates (eds.), The thinking organization. San Francisco: Jossey-Bass.

Gioia and Thomas, 1996 - D. A. Gioia and J. B. Thomas, Identity, image and issue interpretation: Sensemaking during strategic change in academia, Administrative Science Quarterly 41 (1996), pp. 370-403.

Goodwin, 2000 • B. Goodwin, Out of control into participation, Emergence 2 (4) (2000), pp. 40-49.

Holland, 1995 • J. H. Holland, Hidden order, Addison-Wesley Publishing, Reading, MA (1995).

House, 1971 • R. J. House, A path goal theory of leader effectiveness, Administrative Science Quarterly 16 (3) (1971), pp. 321-339.

Hunt, 1999 • J. G. Hunt, Transformational/charismatic leadership's transformation of the field: A historical essay, The Leadership Quarterly 10 (2) (1999), pp. 129-144.

Isabella, 1990 - L. A. Isabella, Evolving interpretations as a change unfolds: How managers construe key organizational events, Academy of Management Journal 33 (1) (1990), pp. 7-41. 
Kauffman, 1995 - S. A. Kauffman, At home in the universe: The search for the laws of self-organization and complexity, Oxford University Press, New York (1995).

Kerr and Jermier, 1978 - S. Kerr and J. M. Jermier, Substitutes for leadership: Their meaning and measurement, Organizational Behavior E Human Performance 22 (3) (1978), pp. 375-403.

Knowles, $2001 \cdot$ R. Knowles, Self-organizing leadership: A way of seeing what is happening in organizations and a pathway to coherence, Emergence 3 (4) (2001), pp. 112-117.

Kotter, 1985 - J. P. Kotter, Power and influence: Beyond formal authority, Free Press, New York (1985).

Kotter, 1990 - J. P. Kotter, A force for change: How leadership differs from management, Free Press, New York (1990).

Kotter, 1996 - J. P. Kotter, Leading change, Harvard Business School Press, Boston (1996).

Langley, 1999 - A. Langley, Strategies for theorizing from process data, Academy of Management Review 24 (1999), pp. 691-710.

Likert, 1961 - R. Likert, New patterns of management, McGraw-Hill, New York (1961).

Lorenz, 1963 • E. N. Lorenz, The mechanics of vacillation, Journal of the Atmospheric Sciences 20 (1963), pp. 448-464.

Maguire and McKelvey, 1999 • S. Maguire and B. McKelvey, Complexity and management: Moving from fad to firm foundations, Emergence 1 (2) (1999), pp. 19-61.

Marion and Uhl-Bien, 2001 - R. Marion and M. Uhl-Bien, Leadership in complex organizations, The Leadership Quarterly 12 (4) (2001), pp. 389-418.

McKelvey, 1999 - B. McKelvey, Avoiding complexity catastrophe in coevolutionary pockets: Strategies for rugged landscapes, Organization Science 10 (3) (1999), pp. 294-321.

McKelvey, 2001 - B. McKelvey, What is complexity science? It is really order-creation science, Emergence 3 (1) (2001), pp. 137-157.

McKelvey and Lichtenstein, in press - McKelvey, B., \& Lichtenstein, B. (in press). Toward a theory of emergence by stages: Complexity and enabling leadership. In J. Hazy, J. Goldstein, \& B. Lichtenstein (Eds.), Complex systems leadership theory. Boston: ISCE Publishing.

Meindl et al., 1985 - J. R. Meindl, S. B. Ehrlich, and J. M. Dukerich, The romance of leadership, Administrative Science Quarterly 30 (1) (1985), pp. 78-102.

Miles and Huberman, 1994 - M. B. Miles and A. M. Huberman, Qualitative data analysis, Sage, Thousand Oaks, CA (1994).

Plowman et al., 2007 • D. A. Plowman, L. T. Baker, T. E. Beck, M. Kulkarni, S. T. Solansky, and D. V. Travis, Radical change accidentally: The emergence and amplification of small change, Academy of Management Journal 50 (3) (2007), pp. 513-541.

Prigogine, 1997 - I. Prigogine, The end of certainty, Free Press, New York (1997).

Prigogine and Stengers, 1984 - I. Prigogine and I. Stengers, Order out of chaos: Man's new dialogue with nature, New Science Library, Boulder, CO (1984).

Quinn, 2005 • R. E. Quinn, Moment of greatness, Harvard Business Review 83 (7-8) (2005), pp. 75-83.

Regine and Lewin, $2000 \bullet$ B. Regine and R. Lewin, Leading at the edge: How leaders influence complex systems, Emergence 2 (2) (2000), pp. 5-23.

Richardson and Cilliers, 2001 - K. Richardson and P. Cilliers, Special editors introduction: What is complexity science? A view from different directions, Emergence: A Journal of Complexity Issues in Organizations and Management 3 (1) (2001), pp. 5-23.

Robichaud et al., 2004 • D. Robichaud, H. Giroux, and J. R. Taylor, The metaconversation: The recursive property of language as a key to organizing, Academy of Management Review 29 (4) (2004), pp. 617-634.

Smircich and Stubbart, 1985 - L. Smircich and C. Stubbart, Strategic management in an enacted world, Academy of Management Review 10 (4) (1985), pp. 724-736.

Stacey, $1992 \cdot$ R. Stacey, Managing the unknowable, Jossey-Bass Publishers, San Francisco (1992).

Stacey, $1995 \cdot$ R. Stacey, The science of complexity: An alternative perspective for strategic change processes, Strategic Management Journal 16 (1995), pp. 477-495.

Steers et al., 1996 - R. M. Steers, L. W. Porter, and G. A. Bigley, Motivation and leadership at work (6th ed.), McGraw-Hill, New York (1996).

Thietart and Forgues, 1995 - R. A. Thietart and B. Forgues, Chaos theory and organizations, Organization Science 6 (1995), pp. 19-31.

Thomas et al., 1993 - J. B. Thomas, S. M. Clark, and D. A. Gioia, Strategic sensemaking and organizational performance: Linkages among scanning, interpretation, action, and outcomes, Academy of Management Journal 36 (2) (1993), p. 239.

Weick, 1995 - K. Weick, Sensemaking in organizations, Sage, Thousand Oaks, CA (1995).

Weick, 1993 - K. E. Weick, The collapse of sensemaking in organizations: The Mann Gulch disaster, Administrative Science Quarterly 38 (1993), pp. 628-652.

Weick and Quinn, 1999 - K. Weick and R. Quinn, Organizational change and development, American Review of Psychology 50 (1999), pp. 361-386.

Wheatley, $1999 \cdot \mathrm{M}$. Wheatley, Leadership and the new science, Berrett-Koehler, San Francisco (1999).

Yin, 2003 - R. K. Yin, Case study research (3rd ed.), Sage Publication, Thousand Oaks (2003).

Yukl, 1989 G. Yukl, Managerial leadership: A review of theory and research, Journal of Management 15 (2) (1989), pp. $251-289$.

Yukl, 2002 G. Yukl, Leadership in organizations (5th ed.), Prentice Hall, Upper Saddle River, NJ (2002). 